\title{
Raktártechnológiai megoldásokkal kapcsolatos menedzsmentdöntések
}

\section{Solutions of Warehouse technology in connection with management decisions}

\author{
J. PAULUK \\ Debreceni Egyetem, Ihrig Károly Gazdálkodás- és Szervezéstudományok Doktori Iskola, \\ pauluk.julia@econ.unideb.hu
}

Absztrakt. A tanulmány célja a raktárban meghozott menedzsmentdöntések helykihasználtságra vonatkozó hatásának vizsgálata két vállalat példáján keresztül. Jó döntést csak úgy hozhatunk, ha elötte alaposan feltérképezzük a változtatás lehetséges hatásait, és kellōen megfontoljuk az új rendszer bevezetésének szükségességét. Egy abroncsgyártó vállalat a bevezetett új elrendezés révén nemcsak helykihasználtság javulást, hanem átfutási idő és költségcsökkenést ért el. Ezzel szemben egy rossz döntéssel egy háztartás-vegyipari gyár felborította raktárának múködését óriási problémákat okozva ezzel az anyagáramlásban.

Abstract. The aim of the study is to analyse the effect of management decisions on space utilization of warehouses through two companies' example. The only way to make good decisions is to take into consideration the possible effects of changes. One of the tire manufacturing companies managed to improve space utilization, caused not only time but cost reduction. On the contrary, a bad decision of a household chemical factory induced enormous problems in the material flow.

\section{Bevezetés}

Tanulmányomban a tárolási mód változtatásával kapcsolatos menedzsment döntések helykihasználtságra gyakorolt hatását vizsgálom meg két multinacionális vállalat esetében. Napjainkban szinte minden termelő és kereskedelmi vállalat esetében kulcsfontosságú jelentősége van a raktárnak, illetve az itt zajló folyamatoknak. A vállalatok egyre inkább arra törekednek, hogy a raktári folyamatok zavartalan működését fenntartva költségcsökkentést érjenek el. Így a raktár működése folyamatosan változik, új, a hatékonyabb munkavégzést elősegítő eszközöket, rendszereket vezetnek be. Igyekeznek javítani a munkakörülményeken, a folyamatok átláthatóságán és a biztonságon.[7] Ennek elérése érdekében ezért gyakran megváltoztatják az eszközöket, a tárolási módot, és az egyes munkafolyamatokat, remélve, hogy ezáltal csökkennek a logisztikával kapcsolatos költségek. Az esetek többségében ezek a menedzsmentdöntések - ha alapos hatásvizsgálatok előzik meg a bevezetés előtt őket - beváltják a hozzájuk füzött reményeket. Javul a múködés, ezzel egy időben 
csökkenhet a költség. Azonban előfordulhat az is, hogy a menedzsment rosszul dönt, a bevezetés előtt nem gondolja át a változtatás hatásait, így problémák sorát okozza ezzel a raktárban.

\section{A raktározás}

A raktárak célja, hogy a vállalatok könnyen ki tudják elégíteni a vevői rendeléseket, ezért különböző hosszúságú ideig javakat tárolnak bennük.[1] Emellett a raktározás azt a célt is szolgálja, hogy kiküszöbölje a termelés során felmerülő ütemkülönbségeket, melyek az ellátási lánc egymást követő fázisai között merülnek fel. [6] A raktárak alapfolyamatát két fő komponens alkotja. Az egyik a mozgási műveleteket, mint például a rakodás, anyagmozgatás foglalja magában, a másik alkotórész pedig a nyugvási, azaz tárolási műveletet tartalmazza. Ez az alapfolyamat még kiegészül számos részfolyamattal, így hozva ezzel létre a raktározási folyamatokat. [9]A raktárak tervezését, kialakítását ezen folyamatoknak a figyelembevételével kell végrehajtani. A tárolás anyagmozgatásának kialakításánál például az egyik legfontosabb elv, amit minden vállalat figyelembe vesz, a helykihasználás. Mindig arra kell törekedni, hogy minimalizáljuk a raktározás miatti anyagmozgatást. A vállalatok általában a leggyakrabban ki- és betárolt anyagokat helyezik el úgy, hogy azok a legrövidebb úton elérhetőek legyenek, illetve igyekeznek az egységrakományokat úgy kialakítani, hogy az a rendelkezésre álló helyet a legjobban kihasználja. (Ez általában azt jelenti, hogy ugyanakkora készlet kevesebb tárhelyet vegyen igénybe az adott raktárban, amit az elrendezés megváltoztatásával érnek el.) [5]

A raktári tárolási rendszerek három fő típusát különböztetjük meg:

- állványok nélküli statikus tárolási rendszerek,

- állványos statikus tárolási rendszerek,

- állványos dinamikus tárolási rendszerek. [4]

Állványos tárolásnál általában az áru vagy csomagolása nem rendelkezik megfelelő mértékű szilárdsággal, így nem lehet belőlük stabil halmazt képezni. Emellett ha minden árufajtához és árucikkhez kívánatos tetszőleges rendszerességgel hozzáférni, vagy állványkiszolgálógépes anyagmozgatási rendszerről van szó, érdemes ezt a tárolási rendszert kialakítani. Ezen belül megkülönböztetünk polcos, tárolóládás, rekeszes, konzolos és át- illetve bejárható állványos tárolást.

A rekeszes állványos tárolás minden egységrakományhoz közvetlen hozzáférést biztosít, és rakodólapos, tárolókeretes, nagyméretű tárolóládás egységrakományokat tároló raktárakban alkalmazható. Általánosságban véve a tartóoszlopok távolsága és mélysége a szabványos rakodólapok méreteihez alkalmazkodik. Bizonyos esetekben 2-3 rakodólapos egységrakományt is el lehet helyezni egy rekeszben. A magasság (amely az alkalmazott anyagmozgató gép rakodási magasságának függvénye) tág határok között mozoghat, egészen 0,4 métertől akár 1,6 méterig. Éppen ezért az állványelemek lehetővé teszik a rakományt alátámasztó hossztartók osztásváltoztatását is. Ezt különböző megoldásokkal lehet megvalósítani. A rekeszes állványokat emelőtargoncákkal, felrakógépekkel, illetve akár felrakódarukkal is ki lehet szolgálni. [8] Az általam vizsgált mindkét vállalatnál állványos tárolást alkalmaznak. 


\section{A tárolási mód megváltoztatásának hatása a helykihasználtságra}

Két multinacionális vállalat raktárában végeztem azzal kapcsolatban kutatást, hogy a tárolási mód megváltoztatása milyen hatással van a helykihasználtságra. Egy gumiabroncs gyártó vállalat 22,86\%os helymegtakarítást ért el azzal, hogy bevezetett egy újfajta késztermék elrendezést az állványokon belül. A helymegtakarításon túl a költségeik és az átfutási idejük is jelentősen csökkent.

Egy háztartási-vegyipari gyárban azonban a költségcsökkentésre irányuló változtatás nem váltotta be a hozzáfüzött reményeket. Ebben az esetben a csomagolóanyag raktárban az Euro raklapok alkalmazásáról áttértek az ipari raklapok használatára. Ezzel jelentősen lecsökkentették a szállítási költségeket, azonban a polcos tárolásnál fennakadásokat okozott. Az egyes polchelyekre ugyanis a korábbi 3 Euro (1200x800 mm) raklap helyett már csak 2 ipari raklap (1200x1000 mm) fért, ezáltal a csomagolóanyag raktárban óriási helyhiány keletkezett. Annyi problémát generált az új rendszer, hogy valószínűleg a járulékos költségek messze felülmúlják a szállítási költség csökkentéséből származó hasznokat.

A tanulmányban az előbb bemutatott két cégnél történt vizsgálatok módját, eredményeit szeretném közölni.Hangsúlyozni szeretném, hogy milyen fontos szerepet töltenek be a vállalatok életében a raktárakban az egyes tárolási móddal kapcsolatos döntések. Bármilyen változtatást hajtunk végre ezekben a létesítményekben elengedhetetlen, hogy előtte alapos vizsgálatokat folytassunk a lehetséges hatásokról, amihez természetesen szükségszerű, hogy az egyes folyamatokat befolyásoló tényezőket minél pontosabban meghatározzuk.

\subsection{A gumiabroncsgyártó vállalat példája}

A raktári helykihasználtság növelése és egyidejűleg a költségcsökkentés érdekében bevezetett új módszerek közül először egy sikeres változtatást, a gumiabroncsgyártó vállalat példáját szeretném bemutatni.A vállalat raktárában a gumiabroncsokat kétféleképp tárolják az állványokban. Az egyik tárolási mód a hagyományosnak mondható „rollos”, amikor az abroncsok az állványokban állítva helyezkednek el, és peremükkel egymáshoz simulnak. Ezzel szemben bevezettek egy új tárolási módot, a „láncos” tárolást, ahol az alsó sor abroncsot nem állítva, hanem megdöntve helyezik el az állványban, a következő sort pedig ezzel ellentétes irányban és az alsó abroncsok közepébe füzik, és így tovább, amíg már több sor nem fér az állványba. A módszer tulajdonképpen a nevét is onnan kapta, hogy első ránézésre a gumiabroncsok szorosan egymásba kapcsolódva, láncszerűen összefüzve találhatók.

A helykihasználtságra vonatkozó elemzésemegyik fő formája az esettanulmány volt. Ez azt jelenti, hogy „egy adott csoportot vagy eseményt figyelünk meg egy adott időpontban, általában egy olyan jelenséget követően, amely valamilyen változást idézett elő”. [2] Jelen esetben ez a változás a „láncos” tárolás bevezetése volt.

Fontos tudni, hogy az új tárolási elrendezés használatát tulajdonképpen az abroncsok mérete határozza meg. Egy bizonyos méret felett ugyanis már fizikailag nem lehet kivitelezni a „láncos” tárolást, és egyébként ez nem is éri meg, mert nem lehet több abroncsot elhelyezni az állványban. 
Ezért ezeknél az abroncsoknál megmaradt a régi „rollos” tárolás. Vizsgálatom első lépéseként összegyűjtöttem cikkszámok szerint az egy állványban maximálisan elhelyezhető abroncsok számát „rollos” illetve „láncos” tárolás esetén is. Összesen 617 cikkszámot vizsgáltam. Az egy állványba rakható termékek száma nagyon változó volt. Például 145/70 R13-as méret esetén akár 70 darabot is össze lehet füzni egy állványban, míg 235/45 R18-ból ez a szám már csak 32. Az 1. táblázat alapján látható, hogy valóban nagyon változatosak az abroncsok tárolás szerinti darabszámai.

\begin{tabular}{|l|c|c|}
\hline Azonosító & DB/ÁLLVÁNY ROLLBAN & DB/ÁLLVÁNY LÁNCBAN \\
\hline A232 & 48 & 70 \\
\hline A249 & 44 & 66 \\
\hline A647 & 40 & 60 \\
\hline A526 & 40 & 56 \\
\hline A258 & 36 & 56 \\
\hline A500 & 36 & 54 \\
A376 & 32 & 44 \\
A446 & 32 & 38 \\
\hline A569 & 28 & 32 \\
\hline A403 & 18 & 18 \\
\hline
\end{tabular}

1. Táblázat: Az abroncsok állványonkénti darabszáma „rollos” és „láncos” tárolás esetén

(Forrás: Saját szerkesztés)

Az 1. táblázat alapján megállapítható, hogy van olyan abroncs, amiből 66 darabot lehet láncban tárolni, míg rollban ez az érték csak 44 darab. Viszont olyan esetet is megfigyelhetünk, amikor láncban csupán 4 db-bal többet tudnak egy állványban tárolni. Így kijelenthetjük, hogy a termékek méreteinek változatossága, ebből adódóan pedig az állványokban tárolható abroncsok darabszáma fogja meghatározni a helymegtakarítás nagyságát.

Voltak olyan cikkszámok, melyek esetében nem találtam kész adatot a céges adatbázisban. Ebben az esetben kerestem hasonló méretú és fajtájú abroncsokat, és az ezekhez tartozó adatokat használtam fel. A dolgozókkal készített interjúk során ezeket ellenőriztem, és a hiányzó cikkszámokhoz tartozó értékeket a raktárosok tapasztalatai és becslései alapján egészítettem ki a táblázatban.

A következő lépésben meghatároztam a készleteket. Először egy éves átlagot számoltam 1 évre visszamenőleg oly módon, hogy minden hónapra külön-külön meghatároztam a napi készletállományokból egy havi átlagot, és ebből pedigaz éves átlagot. Éves átlagban 192.578 darab abroncs van a raktárbanláncban tárolva. Az átlagkészlet alapján ezt követően meghatároztam, hogy az a kétféle tárolási mód szerint hány darab állványt tenne ki. Eredményül azt kaptam, hogy „rollos” tárolás esetén 5.289 darab állványt foglalna el az éves átlagkészlet, míg ez a szám „láncos” tárolás esetén csak 3.968 darab állványt jelentene. A kettő közti különbség tehát 5.289 - 3.968 = 1.321 paletta, ami jelentősnek mondható, hiszen egy átlagos lokációt (ahová 24 állvány fér) véve a raktárban, ez nagyjából 55 tárhelynyi (sornyi) szabad helyet jelent. Ami a százalékos tárhely megtakarítást illeti, ha elosztjuk a „láncos” tárolás palettaszámát a „rollos” tároláséval, akkor eredményül 75,02\%-ot kapunk. Tehát ez alapján kijelenthetjük, hogy a láncba történő összefüzés kerekítve 25\%-os megtakarítást eredményezett. Azonban ez az érték nem tükrözi jól a valódi készletnagyságot, mert jelentős szezonális hatások (például a téli abroncsról a nyárira váltás és fordítva) miatt a készletek szintje a 
szezonok előtt hirtelen megugrik, annak ellenére, hogy a készletforgási sebesség igen nagy. Ezért kiszámoltam egy hónap minden napjára külön-külön a napi készleteket, hogy a napi átlagok alapján a valóságnak jobban megfelelő képet kapjak a tárhely-megtakarításról. A 2. táblázat tartalmazza az egyes napi készletállományokra elvégezve az előbbi vizsgálatot, vagyis hogy hány darab állványon férne el a készlet, ha „rollban”, illetve „láncban” tárolnánk, illetve hogy mekkora helymegtakarítást ért el ezzel a módszerrel a raktár.

\begin{tabular}{|c|c|c|c|}
\hline Dátum & Rollban (db paletta) & Láncban (db paletta) & Küiönbség (\%) \\
\hline 2014.07 .01 & 5461 & 4197 & $23,15 \%$ \\
\hline 2014.07 .02 & 5470 & 4208 & $23,07 \%$ \\
\hline 2014.07 .03 & 5694 & 4373 & $23,20 \%$ \\
\hline 2014.07 .04 & 5685 & 4355 & $23,39 \%$ \\
\hline 2014.07 .05 & 5691 & 4359 & $23,41 \%$ \\
\hline 2014.07 .06 & 5440 & 4200 & $22,79 \%$ \\
\hline 2014.07 .07 & 5415 & 4184 & $22,73 \%$ \\
\hline 2014.07 .08 & 5239 & 4044 & $22,81 \%$ \\
\hline 2014.07 .09 & 5219 & 4022 & $22,94 \%$ \\
\hline 2014.07 .10 & 5515 & 4220 & $23,48 \%$ \\
\hline 2014.07 .11 & 5521 & 4378 & $20,70 \%$ \\
\hline 2014.07 .12 & 5506 & 4183 & $24,03 \%$ \\
\hline 2014.07 .13 & 5528 & 4194 & $24,13 \%$ \\
\hline 2014.07 .14 & 5731 & 4497 & $21,53 \%$ \\
\hline 2014.07 .15 & 5652 & 4443 & $21,39 \%$ \\
\hline 2014.07 .16 & 5967 & 4862 & $18,52 \%$ \\
\hline 2014.07 .17 & 6048 & 4715 & $22,04 \%$ \\
\hline 2014.07 .18 & 6157 & 4927 & $19,98 \%$ \\
\hline 2014.07 .19 & 6185 & 4731 & $23,51 \%$ \\
\hline 2014.07 .20 & 6043 & 4634 & $23,32 \%$ \\
\hline 2014.07 .21 & 6001 & 4582 & $23,65 \%$ \\
\hline 2014.07 .22 & 6013 & 4590 & $23,67 \%$ \\
\hline 2014.07 .23 & 5891 & 4493 & $23,73 \%$ \\
\hline 2014.07 .24 & 6063 & 4628 & $23,67 \%$ \\
\hline 2014.07 .25 & 6274 & 4791 & $23,64 \%$ \\
\hline 2014.07 .26 & 6159 & 4712 & $23,49 \%$ \\
\hline 2014.07 .27 & 6164 & 4730 & $23,26 \%$ \\
\hline 2014.07 .28 & 6084 & 4670 & $23,24 \%$ \\
\hline 2014.07 .29 & 6043 & 4634 & $23,32 \%$ \\
\hline 2014.07 .30 & 6185 & 4740 & $23,36 \%$ \\
\hline 2014.07 .31 & 5913 & 4527 & $23,44 \%$ \\
\hline Átlag & 5805 & 4478 & $22,86 \%$ \\
\hline
\end{tabular}

2. Táblázat: Július havi napi állványszám a kétféle tárolási mód szerint

(Forrás: Saját szerkesztés)

Ahogy az a 2. táblázatból is látszik, a július hónapra számolt készletekből a „láncos” tárolás alkalmazásával átlagosan 22,86\%-os megtakarítást ért el a raktár. Az éves átlagkészlet alapján számolt megtakarítás 25\%-os volt szemben a havi 22,86\%-os értékkel. Ebből azt a következtetést vonhatjuk le, hogy az éves átlagkészlettel számolt értékek kissé torzítanak, viszont ez a pár százalék azt gondolom nem mondható jelentősnek. Megállapíthatjuk, hogy az új rendszer bevezetésével a raktár jól járt, ennek révén rengeteg állvány és lokáció szabadult fel, aminek következtében valószínúleg nem fognak helyhiánnyal küzdeni, amennyiben a készletek nagysága nem emelkedik meg hirtelen. Emellett a bérraktárak számának csökkentése jelentős átfutási idő csökkenéshez és költségmegtakarításhoz vezetett, így a menedzsment helyesen döntött a változtatásról.

\subsection{A háztartás-vegyipari gyárnál végzett vizsgálat}

Az előző fejezetben láthattuk, milyen jelentőséggel bír a raktárban alkalmazott tárolási mód megváltoztatása. Azonban vannak esetek, amikor egy döntés következtében az addig jól múködő rendszerben komoly problémák keletkeznek. Ez történt egy háztartási vegyipari gyár csomagolóanyag 
raktárában is. A költségek redukálása (különösen a szállítási költségek tekintetében) és a jobb helykihasználás érdekében az Euro raklapos (E1: 1200x800 mm) rendszerről áttértek az úgynevezett ipari raklapos (E2: 1200x1000 mm) tárolási rendszerre. Sajnos az azóta eltelt idő során kiderült, hogy az előzetes várakozásokkal szemben csak részben sikerült megvalósítani a kitűzött célokat. Habár a szállítási költségek jelentősen csökkentek, a csomagolóanyag raktárban az új típusú paletták alkalmazása helyhiányt generált.

Manapság már egyik multinacionális cég gyártó üzeme sem engedheti meg magának, hogy a csomagolóanyag nem megfelelősége vagy hiánya miatt leálljon a termelés, és a keresletet ne sikerüljön maximálisan kielégíteni, így a vevői elégedettség mutatók pedig romoljanak. A helyhiánnyal küzdő vállalatnál először azt vizsgáltam meg, hogy nem tartanak-e valamelyik csomagolóanyagból irreálisan magas készletet. Miután ezt az eshetőséget kizártam, a hibát magában a rendszerben kezdtem el keresni, vagyis a bevezetett új raklapos tárolási rendszerben, és annak működésében. Pár éve még kis „Euro” (E1-es) raklapos (1200x800 mm) tárolás volt érvényben, amelyből egy tárhelyre maximum három fér. Ezután áttértek a nagy „ipari” (E2-es) raklapok (1200x1000) használatára, melyből már csak kettőt tudnak egymás mellé rakni. Azt vizsgáltam meg, hogy a jelenlegi meglévő készletek mellett melyik rendszer bizonyul hatékonyabbnak. Abban az esetben, ha a kis raklapos tárolásnál ugyanekkora csomagolóanyag-szintnél marad üres tárhely, a vezetőségnek át kell gondolni, hogy visszatérjenek a régi tárolási rendszerre.

Fontos megemlíteni, hogy a csomagolóanyagok tárhelyei a gyárban korlátozott számúak, az a lehetőség, hogy esetleg egy másik raktárt építsenek az elrendezésből adódóan kizárt. Hiszen a költségek minimalizálása és az időtakarékosság miatt a csomagolóanyagokat közvetlenül a felhasználás helye mellett tárolják.

A régi és az új rendszer összehasonlítását a releváns adatok összegyűjtésével kezdtem. Az összes csomagolóanyag raktárban tartott anyag cikkszámához hozzárendeltem az ahhoz tartozó átlagos készletállományt. Ezután meg kellett keresnem az Euro és az ipari raklapra vonatkozó egy raklapon maximálisan tárolható mennyiségeket. A kutatást nehezítette, hogy a régi rendszerre vonatkozó adatok nem álltak teljes egészében rendelkezésre. Azért hogy a táblázatok a hiányzó adatok ellenére is teljes legyenek, igyekeztem egyenként, cikkszámok szerint megvizsgálni a csomagolóanyagokat. Volt köztük több olyan, amely lényegében ugyanazt a csomagolóanyagot jelentette, csak mivel más országba szánták, más cikkszámot kapott. Ebben az esetben, ha már volt valamelyik cikkszámhoz adat, a másikhoz is ugyanazokat az adatokat használtam. Bizonyos csomagolóanyagok esetében (mint például a kupakok) megmaradt a régi Euro raklapos tárolás. Azon csomagolóanyagok esetében, amelyek a jelenlegi rendszerben is kisméretű raklapon érkeznek, az E1-esen tárolt mennyiségeket írtam be az E2-esekhez is (hiszen az ipari raklapra vagy a tömege vagy a mérete miatt nem tudnának többet rakni).

Miután összegyűjtöttem a szükséges adatokat és táblázatokba rendszereztem, kiszámoltam, hogy az egyes cikkszámok átlagkészlete mennyi helyet foglal. Ezt úgy kaptam meg, hogy az átlagkészletet elosztottam az egy raklapra maximálisan pakolható mennyiséggel. Ezt a számítást elvégeztem különkülön mind a két raklaptípusra, majd hogy teljesebb képet kapjak, a kapott eredményeket felkerekítettem. Erre azért volt szükség, mert a helyfoglalás szempontjából csak egész raklapokkal 
lehet számolni. Eredményül azt kaptam, hogy a régi raklapos tárolás esetén 716, a mostani rendszerben pedig 590 tárhelyet foglal az átlagkészlet. Ez azonban nem jelenti azt, hogy a mostani rendszer jobb lenne az előzőnél, mert az Euro raklapokból 3, az ipari raklapból pedig csak 2 fér be egy tárhelyre. Ezért meg kellett vizsgálnom, hogy összesen hány Euro és hány ipari raklap fér be a raktárba.

Soronként számoltam meg a helyeket, mivel a tűz- és balesetvédelmi szabályok és egyéb különböző fizikai akadályok (például a kupaktöltők miatt az azok feletti tárhelyekhez nem tud hozzáférni a targonca) miatt a vállalat kevesebb tárhelyet tud használni, mint ahogy az a rendszerben van. Összesen 973 Euro raklap fér be a cég csomagolóanyag raktárába, míg a mostani rendszerben ez a szám 705 az ipari raklapok esetében. Bizonyos sorokat nem használnak, például ilyen az A utca, ahol a különböző tesztekhez szükséges anyagokat, zárolt cikkszámú dobozokat, kupakokat és egyéb hulladék anyagokat tárolják. Ezen kívül az utca szűkössége miatt a targoncák nem tudnak megfelelő biztonsággal közlekedni. Technikai okok miatt pedig az első keresztben lévő sorra sem lehet pakolni, mert a polcok alatt conveyor pályák futnak. Így a ténylegesen használt tárhelyek száma lényegesen kevesebb, azaz E1-esből 909, E2-esből pedig 653.

Következő lépésként megvizsgáltam a raktár kihasználtságát mind a két rendszerre vonatkozóan a következő módon: azt, hogy az átlagkészletek hány raklapon férnek el a két rendszerben külön-külön elosztottam a hozzájuk tartozó megfelelő ténylegesen használt tárhelyek számával. Tehát az ipari raklapos tárolási rendszer esetén ez a következőképp néz ki: 590/653=0,9035, vagyis a raktár kihasználtsága kerekítve 90\%-os. Ugyanez az érték Euro raklapok használata esetén: 716/909= 0,7877, azaz körülbelül 79\%.

Ugyanezt a számítást elvégeztem úgy is, hogy a kupakokat nem vettem számításba. Mivel ezekből plusz mennyiséget is tartanak, és külön tárhelyeik is vannak a raktárban, a gondot nagyrészt a dobozbeérkezések jelentik. Két beszállítótól érkeznek a hullámpapírdobozok a gyárba, sok esetben éppen akkorra, amikorra a gyártósoroknak szüksége van rájuk. Sok probléma adódott abból, hogy a sürgős cikkszámú csomagolóanyagokat a berakodáskor a kamionok elejébe teszik, így a raktárosoknak az egész rakományt le kell szedni, hogy hozzájussanak azokhoz az anyagokhoz, amelyekre a sorok várnak. Azonban a raktárban lévő szabad tárhelyek korlátozottsága miatt sokszor ez lehetetlen, hiszen a csomagolóanyag bevételezésnél sincs elegendő hely, az udvarra pedig tilos rakodni. Ez fóként hétvégente okozott nagy problémát, hiszen a hétvégi igények kielégítésére már pénteken beérkeznek a szállítmányok. A raktár kihasználtság a dobozok esetében a következő módon alakul:

A régi raklapos tárolás szerint 829 hely van a raktárban, az átlagos dobozkészlet pedig 489 raklapot tesz ki. Így 489/829= 0,5898, azaz körülbelül 59\%-os a kihasználtság.

Az új rendszerben 579 hely, 364 raklapnyi készlet van átlagban, ezért itt a kihasználtság 364/579= 0,6286, kerekítve 63\%-os.

Mivel kihasználtságról van szó, minél kisebb a kapott szám, annál előnyösebb az a vállalat számára, hiszen nem merül fel abból adódóan probléma, hogy a beérkezett kamionokról a csomagolóanyagokat a raktár túlterheltsége miatt nem tudják leszedni. A fentebbi számításaim tehát igazolja azt a hipotézist, hogy a régi rendszer hatékonyabban múködött, mint a mostani. Az, hogy a kapott számok 
viszonylag alacsonynak tűnnek, nem jelenti azt, hogy a csomagolóanyagok „kényelmesen elférnek” a raktárban. Ez csak egy átlagkészletből történt számítás, a valóságban leggyakrabban szélsőséges esetek fordulnak elő: bizonyos termékek gyártása előtt az adott csomagolóanyag készletek lényegesen megemelkednek, míg mások, amelyeket éppen már legyártottak, minimálisra csökkennek.

Kutatásom során egy szélsőséges esetet is megvizsgáltam. A csomagolóanyag beérkezések száma az egyik héten úgy megnőtt, hogy a raktárosok annak ellenére, hogy minden szabad helyre ahova csak tudtak (például a flakonfújó cég területének egy részére is, amiből később konfliktus is keletkezett) több kamionról sem tudtak lerakodni a csomagolóanyag raktár telítettsége miatt. Mivel a sürgős csomagolóanyagokat sem tudták felküldeni a raktárba, több gyártósor is megállt. Ekkor szintén elvégeztem az előbbi számítást. Az aktuális készletállomány alapján kiszámítottam az Euro és ipari raklapos rendszerre vonatkozó adatokat, majd külön-külön kiszámoltam a raktár terheltségét. Ez a régi rendszer esetén 119\%-os, a jelenlegi rendszerben pedig 137\% volt. Jól látható, hogy az Euro raklapokat használva egyértelműen kisebb lett volna a túlterheltség. Habár így se fért volna be az összes beszállított csomagolóanyag, de éppen le tudták volna rakodni a sürgős csomagolóanyagokat.

Az interjúk során kiderült az is, hogy több raktáros az Euro raklapos rendszert sokkal hatékonyabbnak találta, mint a mostanit. Ennek egyik oka, hogy a kamionra ezeket a raklapokat úgy lehet egymás mellé rakni, hogy a targoncával közvetlenül ki lehessen hozni azokat a szállítójármúből. Tehát míg az Euro raklapokat hármasával és hosszirányba lehet tenni, addig az ipari raklapok kettesével és keresztbe fordítva találhatók a fuvareszközön.

Emellett az ipari raklap lerakodásánál a dolgozóknak kétszer kell ráfordulni az anyagmozgató berendezéssel a raklapra, mivel azok keresztben vannak, és először megfelelő helyzetbe kell forgatniuk. Ezzel a plusz művelettel szintén időt veszítenek. Az itt leírtak alapján tehát kijelenthetem, hogy valóban hatékonyabb volt a régi Euro raklapos tárolás. Az áruáramlás gyorsabb és zökkenőmentesebb volt, mint az ipari raklapos rendszerben, tehát a menedzsment változtatásra irányuló döntése elhamarkodott volt, így komoly veszteségeket generált.

\section{Következtetések és javaslatok}

A fent bemutatott két példa jól mutatja a raktárban alkalmazott tárolási mód megválasztásának jelentőségét. A kutatásom során végzett elemzések és az ezekből levezetett eredmények részletes ismertetése alapján kijelenthetem, hogy a gumiabroncsgyártó vállalatnál hozott döntés eredményes volt, vagyis a „láncban” történő tárolás valóban helytakarékosabb, mint a „rollos” rendszer. A megtakarítás várakozásomon felüli volt, így valószínűleg a jövőben sokkal kevesebb bérraktárra lesz szüksége a vállalatnak, amivel nem csak az átfutási időt csökkentik le jelentősen, hanem az ezekkel kapcsolatos költségeket is. A javaslatom az lenne, hogy ne változtassanak a "láncban” történő tároláson, legalább is addig nem, amíg nem jelentkezik egy újabb, ennél is helytakarékosabb megoldás a gumiabroncsok állványban történő tárolására.

Sajnos a másik, vagyis a háztartási-vegyipari gyár esetében a változás nem teljesen váltotta be a hozzá füzött reményeket. A szállítási költségek jelentősen csökkentek, de cserében óriási zavarok keletkeztek a működésben, azon belül is a tárolással kapcsolatban. Azt javasoltam, hogy térjenek 
vissza a régi, Euro raklapos tárolási rendszerre, mivel a polcrendszer is erre a raklaptípusra lett kialakítva, és a raktárosok is szívesebben dolgoznának vele, így a múködés hatékonyságát ezzel nagyban javíthatnák. Habár az ipari raklapos rendszer a szállítási költségekben jelentős megtakarítást eredményez, ez a helyhiányt és az ebből adódó veszteségeket nem kompenzálja teljes mértékben. Ezen kívül, ha a termelésben is használható bérelt palettákon érkezne az összes csomagolóanyag, jelentős megtakarítások keletkeznének. Egyrészt megoldaná azt a problémát, hogy a csomagolóanyag raktárból a felhasznált csomagolóanyagok alatt lévő raklapokat le kell szállítani, és az udvaron lévő tárolóhelyen kell gyűjteni. Ezzel évente 5 teljes napot takarítottak volna meg. Az új raklapos tárolási rendszer bevezetése óta 13.961 paletta érkezett a gyárba a csomagolóanyagokkal. A targonca egyszerre 15 raklapot bír el, így a raktárosoknak (13.931/15) 931-szer kellett feleslegesen mozgatni a raklapokat. Körülbelül 3 percbe telik, hogy a raktárból leadják és az udvaron keresztül a tárolóba szállítsák a palettákat, illetve átlagosan 5 perc, amíg a kamionra rakodják. Ezért összeadva a szállítás $(931 * 3 m i n=$ 2.793) és a rakodás $(931 * 5 \mathrm{~min}=4.655)$ idejét, 7.448 perc az ezzel elvesztegetett idő. Ez 124 óra, azaz 15,5 műszak. Ezen felül meg kell említeni, hogy a raklapok elszállítását is meg kell szervezni, ami szintén plusz költségeket eredményez. Emellett a hatékonyabb helykihasználás azt eredményezné, hogy lényegesen több tárhely állna rendelkezésre, így ha érkezik egy sürgős szállítmány, azonnal le tudnák szedni, és ezzel elkerülhetőek lennének a csomagolóanyag hiány miatt bekövetkező sormegállások.

\section{5. Összefoglalás}

A termelő és kereskedő vállalatok működésének egy kritikus pontját képezi a raktározás. Nemcsak a gyors és megfelelő vevői igénykielégítést biztosítja, hanem kiküszöböli az ütemkülönbségeket mindamellett, hogy a termékek állagát is megóvja. Mivel a logisztikai költségek jelentős része a raktározással és készletezéssel függ össze, ezért a vállalatoknak különösen oda kell figyelni a raktárban zajló folyamatokra, rendszeresen felül kell vizsgálni a müködést és hiba esetén gyorsan reagálni. Ha szükséges és indokolt, akkor pedig változtatásokat kell eszközölni, legyen az egy tárolási mód váltás vagy egy elrendezés módosítás.

Azonban ahogy arra Guedes et al. [3] is felhívja a figyelmet, a raktár adottságait, tulajdonságait mindenképpen figyelembe kell venni a különböző kulcsfontosságú döntések meghozatala során. Fontos, továbbá az is, hogy céljainkkal és döntéseinkkel összhangban működjön a raktár.

Tanulmányomban két vállalat tárolási móddal kapcsolatos változtatásait elemeztem. Látható, hogy az egyik vállalat vezetése jól döntött, a változtatással jelentős költségmegtakarítást és átfutási idő csökkenést ért el. A másik esetében azonban úgy tűnik, nem volt kellően megalapozott a döntés, amiből jelentős veszteségek keletkeztek. A vezetésnek ebben az esetben komolyan el kell gondolkoznia a régi rendszerre történő visszaállásra és jövőbeli döntéseit alaposabban átgondolva meghozni. 


\section{Hivatkozások}

[1] P. Attwood, N. Attwood (1992), Logistics of a distribution system, Gower Publishing Company Limited, Aldershot, p. 83.

[2] P. Ghauri, K. Gronhaug (2011), Kutatásmódszertan az üzleti tudományokban, Akadémiai Kiadó, Budapest, p. 79.

[3] P. Guedes, R. Saw, A. Waller (1993), Logistics Strategy Planning: Visual Interactive Modelling and Decision Support, In: Strategy Planning in Logistics and Transportation. (Szerk: COOPER, J.) Cogan Page Limited, London, pp. 111-142.

[4] L. Körmendi, J. Pucsek (2011), A logisztika elmélete és gyakorlata, SALDO Pénzügyi Tanácsadó és Informatikai Zrt., Budapest, p. 216.

[5] Z. Kovács, B. Pató Gáborné Szűcs (2008), Raktározás, Nemzeti Szakképzési és Felnőttképzési Intézet, Budapest, p. 67.

[6] Z. Némon (2014), Raktározási ismeretek (Termelési és nagykereskedelmi raktározás), Kereskedelmi és Idegenforgalmi Továbbképző Kft., Budapest, p. 11.

[7] J. Oláh, J. Pauluk J., A „láncos" tárolás helymegtakarításának vizsgálata, Jelenkori Társadalmi és Gazdasági Folyamatok, X. évf. 1. szám, Szerk.: Gál. J. - Gulyás L., Szeged, ISSN 1788-7593, pp. 27-33.

[8] J. Prezenszki J. (szerk.) (2011), Logisztika I. (Bevezető fejezetek), Budapesti Műszaki Egyetem Mérnöktovábbképző Intézet, Budapest, pp. 139-152.

[9] J. Prezenszki (2010), Raktározás-logisztika, Ameropa Kiadó, Budapest, p. 43. 